\title{
MAST1 Gene
}

National Cancer Institute

\section{Source}

National Cancer Institute. MAST1 Gene. NCI Thesaurus. Code C101455.

This gene plays a role in cytoskeletal org anization. 